\title{
Morphological description of the glans penis and baculum of Coendou quichua (Rodentia: Erethizontidae)
}

\author{
Omar Daniel Leon-Alvarado ${ }^{1 *}$ and Héctor E. Ramírez-Chaves ${ }^{2}$ \\ ${ }^{1}$ Laboratorio de Sistemática y Biogeografía, Escuela de Biología, Facultad de Ciencias, Universidad Industrial de Santander. \\ Carrera 27 9, A. A. 678, Bucaramanga, Colombia. E-mail: leon.alvarado12@gmail.com (ODLA) \\ ${ }^{2}$ Departamento de Ciencias Biológicas, Facultad de Ciencias Exactas y Naturales, Universidad de Caldas. Calle 65 26-10, A. A. 275, \\ Manizales, Colombia. E-mail: hector.ramirez@ucaldas.edu.co \\ * Corresponding author
}

External morphology of the glans and baculum are important characters for specific delimitation, especially for rodents (Simson et al. 1995). However, for Erethizontidae there are few descriptive works; in fact, for Neotropical porcupines of the genus Coendou there is just one brief contribution for an indeterminate species by Pocock in 1922. In this work, the morphology of the glans and baculum of Coendou quichua is described. The specimen was collected at the municipality of San Vicente de Chucurí, Santander, Colombia. The penis was dissected and fixed in formaldehyde for one day, and later preserved in ethanol. The baculum was extracted and cleared with potassium hydroxide to be visualized, photographed and measured. The glans and baculum were compared with the description of others porcupines (Erethizon dorsatum and Hystrix brachyura) available in literature, and three additional Neotropical caviomorph rodents (Cuniculus paca, Dasyprocta punctata and Cavia tschudii). The glans length is almost twice the glans head width (Table 1) and comprises the third part of the total penis length. The penis presents a tenuous dark coloration on the head and small tegumentary protuberances formed by 3-4 small spines (Figure 1A). As in other hystricomorph rodents, the glans exhibits an invagination at its tip (sacculus urethralis) which has corrugated walls and presents two conspicuous spikes at the bottom (Figure 1C). Furthermore, the baculum is as large as the C. quichua glans, dorsally concave and ventrally convex (Figure 1B). Although the glans and baculum of $C$. quichua and E. dorsatum are similar, the latter presents larger glans (Table 1), and the sacculus urethralis lacks of corrugated walls and spiny protuberances. When comparing $C$. quichua and $H$. brachyura, the only difference is that the bottom of the sacculus urethralis, near to the spikes is smooth, without spiny protuberances. In contrast, the glans of three other Neotropical caviomorphs are remarkable different from C. quichua, where they present more complex and densely distributed tegumentary protuberances above the glans. Overall, the baculum is the most varying structure for all species, with marked differences in length and width (Table 1) and the shape of the ends. Although the family Erethizontidae is more closed related to the Cavioidea than to Hystricidae, the glans of individuals of the family Erethizontidae are more similar to the glans of the Hystricidae. In addition, for these species, both glans and baculum present important characters that might be used for taxonomic identification. However, the differences of both structures within Coendou are unknown, therefore it is necessary the description of the genitalia of additional species.

La morfología externa del glande y báculo son caracteres importantes para la delimitación de especies, en especial para roedores (Simson et al. 1995). Sin embargo, para Erethizontidae existen pocos trabajos descriptivos; de hecho, para los puercoespines neotropicales del género Coendou solo hay una breve contribución publicada por Pocock en 1922. Aquí, se describe la morfología del glande y báculo de Coendou quichua. El espécimen se recolectó en el municipio de San Vicente de Chucurí, Santander, Colombia. El pene fue extraído y se fijó en formaldehido por un día, para después ser preservado en etanol. El báculo se extrajo del glande y se transparentó con hidróxido de potasio para ser visualizado, fotografiado y medido. El glande y báculo fueron comparados con la descripción de otros puercoespines (Erethizon dorsatum e Hystrix brachyura) disponibles en literatura y adicionalmente con tres roedores caviomorfos neotropicales (Cuniculus paca, Dasyprocta punctata y Cavia tschudii). La longitud del glande es cerca de dos veces el ancho de la cabeza del glande (Tabla 1) y comprende la tercera parte de la longitud total del pene. El pene presenta una coloración oscura tenue en la cabeza y protuberancias epiteliales pequeñas formadas por 3-4 espinas (Figure 1A). Al igual que el resto de roedores histricomorfos, el glande presenta una invaginación en la punta (sacculus urethralis) la cual tiene paredes corrugadas y presenta dos púas conspicuas en el fondo (Figure 1C). Por otro lado, el báculo es igual de largo al glande de C. quichua, cóncavo dorsalmente y convexo ventralmente (Figure 1B). Aunque los glandes y báculos de C. quichua y E. dorsatum son similares, el último presenta un glande más grande (Tabla 1) y el sacculus urethralis no tiene las paredes corrugadas y con protuberancias espinosas. Al comparar $C$. quichua y $H$. brachyura, la única diferencia es que en el fondo del sacculus urethralis, cerca de las púas, es liso y sin protuberancias espinosas. En contraste, los glandes de los otros tres caviomorfos neotropicales son bastante distintos del de C. quichua, donde los de ellos presentan protuberancias epiteliales más complejas y más densamente distribuidas sobre todo el glande. En general, el báculo es la estructura con mayor variación para todas las especies, con diferencias marcadas en el largo y ancho (Tabla 1) y la forma de cada uno de los extremos. A pesar de que la familia Erethizontidae está más relacionada con Cavioidea que con Hystricidae, el glande de los individuos de la familia Erethizontidae es más similar al glande de Hystricidae. Además, para estas especies, el glande y el báculo presentan importantes caracteres que podrían ser usados en taxonomía. Sin embargo, las diferencias dentro de Coendou son desconocidas, por lo cual es necesario la descripción de la genitalia de especies adicionales del género.

Key words: Baculum; Erethizontidae; glans morphology; Quichua porcupine; sacculus urethralis.

(C) 2017 Asociación Mexicana de Mastozoología, www.mastozoologiamexicana.org

\section{Introduction}

The external morphology of the glans and the baculum (os priapi) contains important characters for specific and subspecific delimitation (Rocha-Barbosa et al. 2013), especially in rodents (Lidicker 1968; Bradley and Schmidly 1989; Spor- tono 1979; Simson et al. 1995; Calderón-Capote et al. 2016). However, there are few descriptive studies on the external genitalia morphology of hystricomorph rodents (Tullberg 1899; Pocock 1922; Dathe 1937; Hooper 1961, Atalar and Ceribasi 2006; Adebayo et al. 2011), a clade that includes the 
New World caviomorphs (e. g., New World porcupines, agoutis, acouchis, pacas and Guinean pigs; sensu Upham and Patterson 2015). The New World porcupines of the genus Coendou are distributed on Central and South America (Voss 2011) and represents one of the less studied rodent groups in the Neotropics (Alberico et al. 2000). Due to the scarcity of specimens available for comparisons, the taxonomic status of many species within the genus is still under discussion (see Voss 2011; Voss et al. 2013; Ramírez-Chaves et al. 2016). Furthermore, information on Coendou genitalia is limited; indeed, there is only one brief published description of the male genitalia of an indeterminate species (reffered as Coendou novae-hispaniae) by Pocock (1922). Considering the scarcity of information about these structures in porcupines -and in general in caviomorph rodents- and the possibility to use this information to solve taxonomical problems, in this work we described the morphology of the glans and the baculum of the Quichua porcupine (Coendou quichua).

\section{Materials and methods}

The description is based on one adult specimen collected at the "Finca el Diviso", vereda La Colorada, municipality of San Vicente de Chucurí, Santander, Colombia (6 $6^{\circ} 47^{\prime} 38.27^{\prime \prime} \mathrm{N}$, $-73^{\circ} 28^{\prime} 48.23^{\prime \prime} \mathrm{W} ; 1,400$ masl). The specimen was deposited in the mammalian collection of the Universidad Industrial de Santander (UIS-MHN-M-945). The penis was dissected and fixed in $5 \%$ formaldehyde for one day and later preserved in $95 \%$ ethanol. The baculum was extracted from the glans, and cleared in $5 \%$ potassium hydroxide following Wassersug (1976). Both penis and baculum were photographed. Eight measurements were taken using a dial caliper to the nearest 0.001, following Hooper (1961) and Adebayo et al. (2011), and include: total glans length (TGL), glans head width (GHW), glans base width (GBW), total bacular length (TBL), baculum head width (BHW), baculum base width (BBW), sacculus urethralis spikes length (SusL), and sacculus urethralis length (SUL). In addition, the proportion of the total bacular length / total glans length (TBL / TGL), sacculus urethralis spikes length / sacculus urehtralis length (SusL / SUL) and sacculus urethralis length / total glans length (SUL / TGL), were calculated. For the glans, all measurements and photographs were taken before baculum extraction. The nomenclature for the description of both glans and baculum follows previous works (Pocock 1922; Hooper 1961; Adebayo et al. 2011).

The glans and baculum were compared with the description of these structures in two others porcupines available in literature (Pocock 1922; Hooper 1961), the North American porcupine, Erethizon dorsatum, and the Malayan porcupine, Hystrix brachyura, and three additional Neotropical caviomorph rodents (Hooper 1961): Cuniculus paca, Dasyprocta punctata, and Cavia tschudii.

\section{Results}

The glans length of $C$. quichua is almost twice the glans head width (Table 1) and comprises the third part of the total penis length $(41.2 \mathrm{~mm})$. The glans is cylindrical, with the head wider than the base. The glans exhibits a yellow cream coloration, and as in others hystricomorphs with a notably tenuous dark coloration of the head (Figure $1 \mathrm{~A}$ ), observed pre and post formaldehyde fixation. Another remarkably characteristic of the glans is the presence of small tegumentary protuberances formed by 3-4 small spines (Figure 1D-E). The protuberances are densely distributed in the head of the glans, but scarcely in the base (Figure $1 \mathrm{~A}$ ). At the tip of the glans below to the urethra, there is an invagination called sacculus urethralis (SU). This SU has longitudinally corrugated walls and two developed spikes at the bottom, and as the rest of the glans, presents spiny tegumentary protuberances (Figure 1C). The baculum is as large as the $C$. quichua glans (Table 1 ), dorsally concave and ventrally convex, and have a distal end or head, a medial region or shaft and a proximal end or base. Both ends are wider than the shaft (Table 1), especially the base which is wider than head. Also, the thin shaft becomes wider and robust close to its base (Figure 1B).

\section{Discussion}

The glans shape (cylindrical with a round tip and exhibiting tegumentary protuberances) in C. quichua is similar to three other Neotropical caviomorphs; however, differences are found in the tegumentary protuberances. In C. quichua, E. dorsatum, and Cuniculus paca, the glans exhibit tegumen-

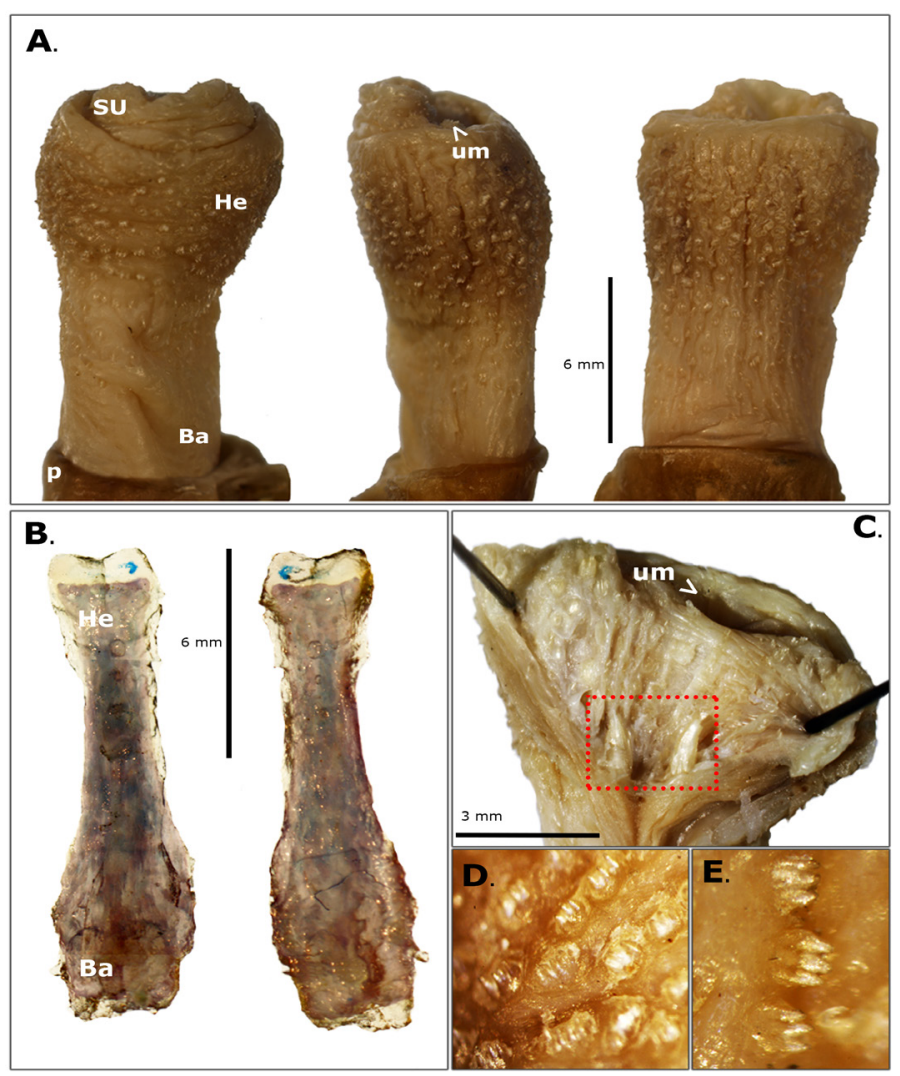

Figure 1. External view of the (A): penis glans, dorsal (left), lateral (middle) and ventral (right) views. SU: sacculus urethralis. He: head. Ba: base. p: prepuce. um: urinary meatus. (B): External view of the baculum, dorsal (left) and ventral (right) views. (C): Ventral internal view of the sacculus urethrlis and the two spikes (red rectangle). (D-E): Close up of the external tegumentary spiny protuberances. 
tary protuberances compound by a single spine (Figure $2 A$ ), with variable size in the latter. Furthermore, Cuniculus paca presents a notably pair of large dorsolateral multi-toothed rasp (Figure 2D) which are absent in the other species. In D. punctata and Cavia tschudii, the protuberances are more complex, transversally oriented, and with a blade-like shape, forming a continuous serrate line (Figure 2B-C). In addition, in Cavia tschudii those serrate lines are larger than in $D$. punctata, and are distributed only in specific places of the glans (Figure 2B). As in other hystricomorph rodents (Tullberg 1899; Pocock 1922; Dathe 1937; Hooper 1961; Atalar and Ceribasi 2006; Adebayo et al. 2011), C. quichua presents a sacculus urethralis ( $\mathrm{SU}$; Figure $1 \mathrm{~A}-\mathrm{C}$ ), an invagination at the tip of the glans below to the urethra, that is everted during erection (Layne 1960; Contreras et al. 1993). When comparing $E$. dorsatum with C. quichua, the SU has smooth and not corrugated walls in the former, lacking of spiny protuberances (Figure 2A). Although the SUL / TGL proportion remains the same for both species, $C$. quichua has longer spikes compared with the length of the SU (Table 1). For the three additional Neotropical caviomorphs compared, the SU is larger when contrasted with the length of the glans, especially for Cavia tschudii (Table 1), which differentiate it from C. quichua. Also, C. quichua and Cuniculus paca have similarsized spikes (compared with the SU length) which are longer than in Cavia tschudii, but are shorter than in D. punctata (Table 1; Figure 2). Finally, as in C. quichua, the walls of the $\mathrm{SU}$ in all three Neotropical caviomorph are corrugated with the presence of tegumentary protuberances (Figure 2B-C).

The baculum is one of the most varying structure among mammal species. The general bacular form in $C$. quichua (head and base wider than the shaft, and the base wider than the head; Figure $2 \mathrm{C}-\mathrm{D}$ ), is similar to the one presented in D. punctata and Cuniculus paca. In contrast, in $E$. dorsatum and Cavia tschudii, only the base of the baculum is wider, while the shaft and head are thinner and have the same width (Hooper 1961). The tip of the head is round in E. dorsatum and the Neotropical caviomorph (Figure 2), but in C. quichua it is flat (Figure 1B). This character seems to be unique for Coendou. In contrast, the base of the baculum in C. quichua is round (Figure 1B), similar to the one observed in Cavia tschudii, whereas for E. dorsatum, D. punctata and Cuniculus paca, the base is flattened with two remarkably lobes at both sides (Hooper 1961; Figure 2).

The comparison of the baculum between $C$. quichua and $H$. brachyura is limited because the brief description of this structure in the latter, which only includes the glans. The glans for both species are similar, being the only difference the bottom of the SU, near to the spikes, which in H. brachyura is smooth, without spiny protuberances (see Pocock 1922).

Although the family Erethizontidae is more closely related to the Cavioidea than to Hystricidae (Huchon and Douzery 2001; Blanga-Kanfi et al. 2009; Antoine et al. 2011), the glans of individuals of the family Erethizontidae are more similar to these of Hystricidae. Dathe (1937) sug-

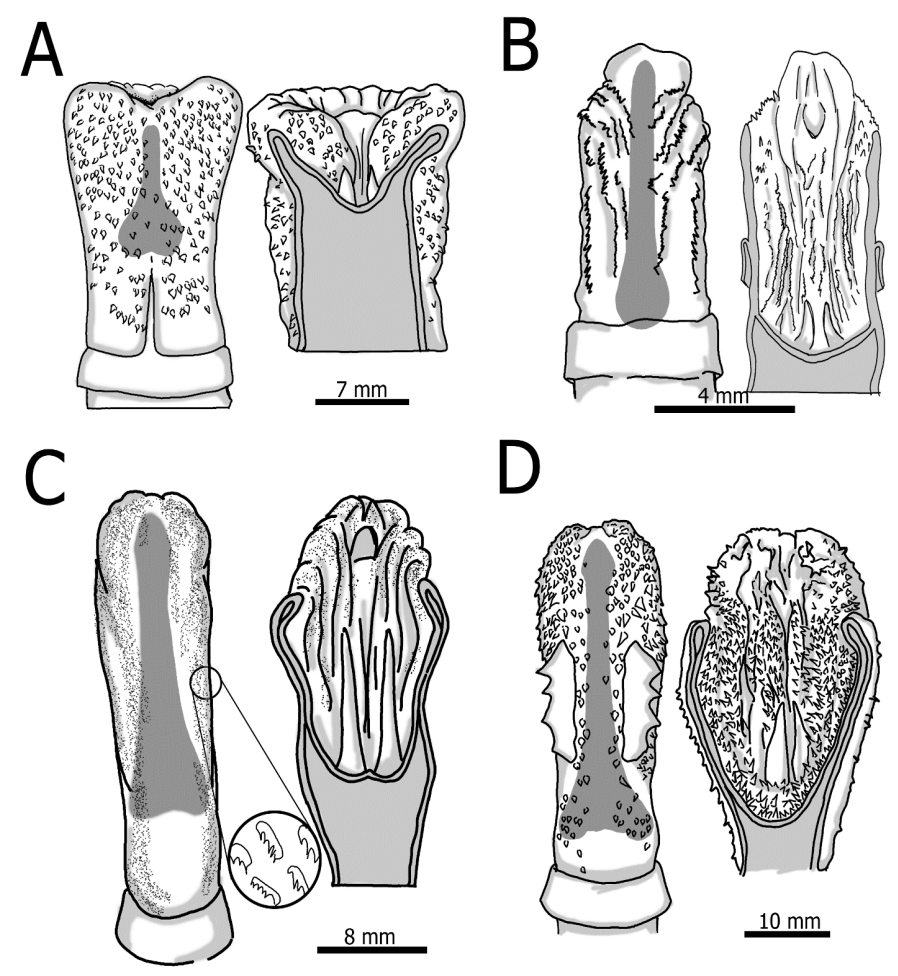

Figure 2. Glans (left), sacculus urethralis (right) and baculum (in gray) for the four species compared: Erethizon dorsatum (A), Cavia tschudii (B), Dasyprocta punctata (C) and Cuniculus paca (D), modified from Hooper (1961).

gested that glans with a heavy armature (tegumentary protuberances) and a deep sacculus urethralis were characteristics of primitive hystricomorphs; however, Erethizontidae is more basal than the Cavioidea, and Hystricidae is the basal group from the Hystricognathi (see Blanga-Kanfi et al. 2009). Due to the similarity in the glans between Erethizontidae and Hystricidae, glans with a slight armature (simply tegumentary protuberances) and a non-deep sacculus urethalis (compared with the total glans length) should be characteristics of primitive hystricomorphs. Whereas, for the baculum, this structure shows no general pattern for all species, and it seems to be characteristic for each genus, especially for $C$. quichua. In contrast, the baculum of the Hystricomorpha compared are clearly different from other rodents, such as Proechymis (see Hooper 1961), Marmota and Citellus (see Burt 1960), and several Sigmodontinae rodents (see Calderón-Capote et al. 2016). In addition, for these species, both glans and baculum exhibit important characters that might be used for taxonomic identification, such as the tegumentary protuberances, SU depth, or the baculum head shape. However, bacular differences within Coendou are still unknown, therefore it is necessary the description of the genitalia of additional species.

\section{Acknowledgements}

Thanks to people at Finca El Diviso, K. A. Méndez-Camacho, D. R Miranda-Esquivel, E. Meneses-Pelayo, and the Grupo de Estudios en Biodiversidad at Universidad Industrial de Santander, especially to the Laboratorio de Entomología. Finally thanks to two anonymous reviewers for their priceless comments on the manuscript. 
Table 1: Glans and baculum measurements (in $\mathrm{mm}$ ). TGL: Total glans length, GHW: Glans head width, GBW: Glans base width, TBL: Total bacular length, BHW: Baculum head width, BBW: Baculum base width, SUsL: Sacculus urethralis spikes length, SUL: Sacculus urethralis Length. There is no information of any measurement for $\mathrm{H}$. brachyura. * Proportion (e. g. ${ }^{*} \mathrm{TBL} / \mathrm{TGL}$ : Proportion of the total bacular length / total glans length). Measurements of additional species taken from Hooper (1961).

\begin{tabular}{lrrrrr}
\hline & $\begin{array}{l}\text { Coendou } \\
\text { quichua }\end{array}$ & $\begin{array}{l}\text { Erethizon } \\
\text { dorsatum }\end{array}$ & $\begin{array}{r}\text { Cuniculus paca } \\
\text { Dasyprocta } \\
\text { punctata }\end{array}$ & $\begin{array}{l}\text { Cavia } \\
\text { tschudii }\end{array}$ \\
\hline TGL & 13.1 & 18.5 & 38.2 & 28.7 & 7.5 \\
GHW & 6.3 & 12 & 15.3 & 8 & 4.7 \\
GBW & 5.05 & 10.3 & 12.1 & 7.5 & 4.9 \\
TBL & 12.9 & 9.2 & 33.1 & 20 & 7.1 \\
BHW & 2.15 & 1.1 & 4.1 & 2.1 & 0.6 \\
BBW & 3.6 & 5.4 & 12 & 5.1 & 1.5 \\
SUsL & 2.01 & 2.1 & 8.5 & 9.5 & 2 \\
SUL & 4.2 & 6.5 & 18 & 13.5 & 8.1 \\
*TBL / TGL & $1: 1$ & $1: 2$ & $1: 1.5$ & $1: 1.43$ & $1: 1$ \\
*SUsL / SUL & $1: 2$ & $1: 3$ & $1: 2.1$ & $1: 1.42$ & $1: 4$ \\
*SUL / TGL & $1: 3$ & $1: 2.8$ & $1: 2.1$ & $1: 2.1$ & $1: 0.9$ \\
\hline
\end{tabular}

\section{References}

Adebayo, A. O., A. K. Akinloye, S. A. Olurode, E. O. Anise, and B. O. OKe. 2011. The structure of the penis with associated baculum in the male greater cane rat (Thryonomys swinderianus). Folia Morphologica 70:197-203.

Alberico, M. V., V. Rojas-D, AND J. G. Moreno. 2000. Aporte sobre la taxonomía y distribución de los puercoespines (Rodentia: Erethizontidae) en Colombia. Revista de la Academia Colombiana de Ciencias Exactas, Físicas y Naturales 23:595612. [dated 1999, printed 2000]

Antoine, P. O., L. Marivaux, D. A. Croft, G. Billet, M. Ganerød, C. Jaramillo, T. Martin, M. J. Orliac, J. Tejada, A. J. Altamirano, F. Duranthon, G. Fanjat, S. Rousse, and R. S. Gismondi. 2011. Middle Eocene rodents from Peruvian Amazonia reveal the pattern and timing of caviomorph origins and biogeography. Proceeding of the Royal Society B 279:1319-1326.

Atalar, O., AND A. O. Ceribasi. 2006. The morphology of the penis in porcupine (Hystrix cristata). Veterinami Medicina 51:66-79.

Blanga-Kanfi, S., H. Miranda, O. Penn, T. Pupko, R. W. DeBry, and D. HuCHON. 2009. Rodent phylogeny revised: analysis of six nuclear genes from all major rodent clades. BMC Evolutionary Biology 9:71.

Bradley, R. D., D. J. Schmidly, and R. D. Owen. 1989. Variation in the glans penis and bacula among Latin American population of the Peromyscus hoylei species complex. Journal of Mammalogy 70:712-725.

Burt, H. W. 1960. Bacula of North American mammals. Miscellaneous Publications of the Museum of Zoology, University of Michigan 113.

Calderón-Capote, M. C., A. Jerez, P. Sánchez-Palomino, and H. F. LópezArÉvalo. 2016. Bacular morphology of seven species of high Andean rodents from Colombia (Rodentia: Sigmodontinae). Mastozoología Neotropical 23:25-37.

Contreras, L. C., J. C. Torres-Mura, A. E. Spotorno, and F. M. Catzeflis. 1993. Morphological variation of the glans penis of South American octodontid and abrocomid rodents. Journal of Mammalogy 74:926-935.
DATHE, H. 1937. Uber den baus des mannlichen kopulationsorganes beim meerschweinchen und anderen hystrycomorphen nagatieren. Jahrbuch fur Morphologie und Mikroskopische Anatomie 80:1-65.

DIDIER, R. 1962. Note sur l'os penien de quelques rongeurs de I'Amerique du Sud. Mammalia 26:408-430.

Hooper, E. T. 1961. The glans penis in Proechimys and other cavimorph rodents. Occasional Papers. Museum of Zoology, University of Michigan 623:1-18.

Huchon, D., and E. J. Douzery. 2001. From the Old World to the New World: A molecular chronicle of the phylogeny and biogeography of Hystricognath Rodents. Molecular Phylogenetics and Evolution 2:238-251.

LAYNE, J. N. 1960. The glans penis and baculum of the rodent Dactylomys dactylinus Desmarest. Mammalia 24:87-92.

LIDICKER, W. Z. 1968. A phylogeny of New Guinea rodent genera based on phallic morphology. Journal of Mammalogy 49:609-643.

Pocock, R. I. 1922. On the external characters of some hystricomorph rodents. Proceedings of the Zoological Society of London 92:365-427.

Ramírez-Chaves, H. E., A. F. Suárez-Castro, D. M. Morales-Martínez, and M. C. Vallejo-Pareja. 2016. Richness and distribution of porcupines (Erethizontidae: Coendou) from Colombia. Mammalia 80:181-191.

Rocha-Barbosa, O., J. S. L. Bernardo, M. F. C. Loguercio, T. R. O. Freitas, J. R. Santos-Mallet, And C. J. Bidau. 2013. Penial morphology in three species of Brazilian Tuco-tucos, Ctenomys torquatus, $C$. minutus and C. flamarioni (Rodentia: Ctenomydae). Brazilian Journal of Biology 73:201-209.

Simson, S., L. Ferruci, C. Kurtonur, B. Özkan, and M. G. Filippucci. 1995. Phalli and Bacula of European Dormice: description and comparison. Hystrix, the Italian Journal of Mammalogy 6:231-244.

SpORTONO, S. 1979. Contrastación de la macrosistemática de roedores caviomorfos por análisis comparativo de la morfología reproductiva masculina. Archivos de Biología y Medicina Experimentales 12:97-106.

Tullberg, T. 1899. Ueber das System der Nagethiere: Eine phylogenetische Studie. Nova Acta Regiae Societatis Scientiarum Upsaliensis Serie 3:1-514.

Upham, N. S., AND B. D. Patterson. 2015. Evolution of the caviomorph rodents: a complete phylogeny timetree of living genera. Pp. 63-120 in Biology of caviomorph rodents: diversity and evolution (Vassallo, A. I. \& Antenucci, D., eds.). SAREM Series A, Buenos Aires.

Voss, R. S. 2011. Revisionary notes on Neotropical porcupines (Rodentia: Erethizontidae) 3. An annotated checklist of the species Coendou Lacépède, 1799. American Museum Novatites 3720:1-36.

Voss, R. S., C. Hubbard, and S. A. Jansa. 2013. Phylogenetic relationships of New World porcupines (Rodentia: Erethizontidae): implications for taxonomy, morphological evolution, and biogeography. American Museum Novatites 3769:1-36.

WASSERSUG, R. 1976. A procedure for differential staining of cartilage and bone in whole formalin-fixed vertebrates. Stain Technology 51:131-134. 
Associated editor: Pablo Teta

Submitted: April 4, 2017; Reviewed: June 6, 2017;

Accepted: June 14, 2017; Published on line: July 6, 2017. 
GLANS AND BACULUM MORPHOLOGY

268 THERYA Vol. 8 (3): 263-268 